\title{
ФЕНОМЕНОЛОГІЯ ДОМАШНЬОГО НАСИЛЬСТВА В УКРАЇНСЬКІЙ ПРАВОВІЙ ДОКТРИНІ
}

\author{
МАЛИНОВСЬКА Тетяна Миколаївна - кандидат юридичних наук, \\ провідний науковий співробітник науково-дослідної лабораторії 3 проблем \\ протидії злочинності Харківського національного університету внутрішніх справ \\ https://orcid.org/0000-0002-7713-7617 \\ УДК 343.9:343.226(477) \\ DOI 10.32782/LAW.2020.2.21
}

Проведен исторический и сравнительно-правовой анализ существующих научных подходов к природе и содержанию беномена насилия как такового и, в частности, домашнего насилия. Акцентировано внимание на феноменологическом описании домашнего насилия как объекта криминологического исследования. Дана общая характеристика институтов семьи и брака, а также домашних взаимоотношений как наиболее значимьх факторов формирования человеческого поведения в сбере общественной жизни. Отражень точки зрения ученьхх и мыслителей, указываюшие на эволючионный характер феномена домашнего насилия через призму различных сфер познания.

Ключевъг слова: Феноменология, насилие, домашнее насилие, насилие в семье, семья, илен семьи, брак.

\section{Вступ}

Останніми роками в Україні приділяється велика увага проблемам запобіганню та протидії домашньому насильству, яке призводить не тільки до втрати найдорожчого для людини - життя та здоров'я, а також завдає великої соціальної та моральної шкоди суспільству.

Сучасний підхід до проблеми домашнього насильства включає, з одного боку, укоріненість цієї проблеми в суспільній свідомості як міжособистісною, а 3 іншої - виходить 3 обов'язків держави гарантувати права людини в усіх сферах життя, у тому числі і в сім'ї.

Насильство, як асоціальне явище, не тільки формує трагічні обставини для багатьох людей, але й створює криміногенні ситуації, які передують кримінальним злочинам проти безпеки, здоров'я і життя людини, що в цілому руйнує фундамент стабільності суспільства.

3 метою всебічного вивчення злочинності як основного предмета кримінологічної науки, необхідно враховувати складні природні та суспільні явища і процеси, які прямо або опосередковано визначають сам феномен злочинної поведінки, в тому числі - насильницький. Також необхідно звернути особливу увагу на багатоаспектність поняття насильства, і самої реальності, що включає це поняття. 3 урахуванням цієї обставини, дослідницьким об’єктом тут стає досить широке i насичене численними детермінантами проблемне поле. Воно включає в себе комплекс взаємопов'язаних явищ і процесів, які протікають у різних сферах життя суспільства, а також різноманітні характеристики і прояви природи людини.

У науковій статті розглянуто історичний та порівняльний аналіз існуючих підходів до природи і змісту феномену насильства, домашнього насильства. Акцентовано увагу на феноменологічному описі домашнього насильства як об’єкта дослідження в кримінологічному ракурсі. Наведено загальну характеристику сім'ї, шлюбу та домашніх взаємовідносин як найбільш значимих чинників формування людської поведінки у сфері громадського життя. Розглянуті різні підходи вчених та мислителів щодо еволюційного характеру змістовного наповнення феномену домашнього насильства через призму різних сфер пізнання. 


\section{Постановка проблеми}

Сім'я як ланка суспільства, об'єднана спільним домом (побутом), є одним із найдавніших соціальних інститутів, який впродовж всієї історії людського суспільства привертав пильну увагу філософів: Аристотеля, Платона, Бекона, Гоббса, Руссо, Монтеня, Канта, Гегеля, Гуссерля, Шопенгауера, Ніцше, Десницкого, Маркса, Енгельса та інших. Погляд на сім'ю як на соціокультурний феномен і найважливіший інститут соціалізації особистості, історичної трансляції культурних, етнічних, моральних цінностей в тій чи іншій мірі відбивається в філософських працях більшості мислителів минулого і сучасності. До середини XIX століття інститути сім'і, шлюбу та й домашніх взаємовідносин узагалі трактувались як позаісторичні явища, створені відповідно до біблійних настанов, згідно з якими шлюб беруть один чоловік і одна жінка, чоловік є головою сім'ї, якому підкоряються дружина і діти [1, с.17].

Багато в чому уявлення, хто має бути главою в сім'ї, формує стосунки між ії членами, розподіл прав та обов'язків. Як зазначаєА. Блага, системне повторення ситуацій утиску прав жінок або членів сім’ї призводить до формування дискримінаційної поведінки 3 боку домінуючого члена сім”ї та виникнення насильства в сімейних стосунках [1, с.26].

Пізніше, коли погляди на сімейні стосунки стали більш цивілізованими, становлення жінки в суспільстві й сім’ї та їі значущість значно зросли. Окрім того сімейні відносини, взаємозв'язки між батьками та дітьми, права дітей, успадкування були підкріплені джерелами права.

Сьогодні питання насильства розглядається у різних аспектах, саме тому серед безлічі робіт у сфері насильства переважають міждисциплінарні дослідження, що обумовлено комплексним характером самої проблематики насильства.

\section{Стан дослідження проблеми}

Дослідженням понять, пов'язаних із домашнім насильством i насильством взагалі, опікувались учені з різних галузей знань - адміністративного, кримінального права, психології, соціології та інших. Як історико- теоретична категорія, проблематика домашнього насильства (насилля в сім'і) розглянута у працях О. Бандурки, О. Бойко, А. Благої,С. Волошиної, А. Гусейнова, О. Гуміна, О. Ігнатова, Г Кобеньок, Г. Кожухарь, М. Кузнецової, О. Аомакіної, О. Аитвинова, Д. Метілки, Т. Мінки, О. Полковенко, Т. Полковенко,О. Постол, В. Соловйова, О. Храмцова та інших.

Низка важливих теоретико-методологічних і практичних проблем, які мають значення для осмислення обраного як об'єкта дослідження феномену у сфері соціології розглядались Р. Берк, М. Вебером, А. Герасіною, Р. Джеллзом, К. Йолло, А. Аерман, М. Страусом, С. Стейнметцом, Д. Фінкельхор, А. Шерман та ін. Однак попри широке коло наукових досліджень у сфері насильства та захисту прав людини від насильницьких злочинів, велике розмаїття значної кількості форм та чинників пов'язане з феноменом насилля, що має тенденцію до появи нових та трансформації вже існуючих, відсутністю спільного для наук, у чиє предметне поле досліджень входить цей соціальний феномен, дослідження виникнення та існування феномену «насилля» набуває все більшої актуальності

Метою статті є опис та пояснення феномену домашнього насилля, як одного з суперечливих і складних соціокультурних явищ. Завданням є історичний та порівняльний аналіз сучасних підходів до вивчення природи i змісту феномену насильства, домашнього насильства.

Наукова новизна дослідження полягає в обгрунтуванні еволюиійного характеру змістовного наповнення феномену домашнього насильства через призму різних сфер пізнання.

\section{Виклад основного матеріалу}

Сім'я є основоположним осередком будьякої нації або культурної спільноти. Водночас сім'я $є$ дзеркальним відбитком суспільства, оскільки будь-які суспільні зміни відображаються на зовнішній формі та внутрішньому стані людини (морально-психологічному кліматі, побутових умовах, якості життя). Негативний феномен домашнього насильства іманентно властивий соціуму. Як зауважує укра- 


\section{Кримінальне право, кримінальний процес та криміналістика}

їнський дослідник В.Слюсар (2019) у дисертаційному досліджені «Насилля як субстанційна характеристика соціальних трансформацій», одним 3 основних аргументів доведення позиції суб'єктів протистояння донині лишається насилля, яке здійснюється у формі протиборства, війни, гонки озброєнь, локальних конфліктів. Це ж стосується і кожного суспільства, розвиток якого супроводжується різними трансформаційними процесами. Спроби вибудувати соціальний діалог на основі переконання та консенсусу зазнають невдач передусім через позицію його учасників, які, «приватизувавши» певну догму, проголошують себе монополістами на істину. А відтак, єдиною відповіддю на переконання тих, хто утверджує цю істину в соціальній практиці, залишається лише насилля [2, с.5].

Насилля як багатоаспектне поняття включає в себе комплекс взаємопов'язаних явищ i процесів, які протікають у різних сферах життя суспільства, а також мають різноманітні характеристики і прояви природи людини. Як зауважує А. Блага, « ...при розробці основних теоретичних засад запобігання насильству в цілому, та насильству в сім’ї зокрема, слід виходити 3 багатовимірного пояснення цього феномену, в якому немає провідної ролі якогось одного чинника чи складника» [3, с. 250]. Тому на сьогоднішньому етапі розкриття зазначеної проблематики передбачає системність наукового та практичного підходу.

Феноменологічний рівень опису характеристики домашнього насильства як об'єкта дослідження, а також його концептуалізація в кримінологічному ракурсі передбачає потребу чи навіть необхідність виходу за рамки предметної сфери кримінології для залучення методологічного інструментарію, за допомогою застосування якого можна вирішити комплексну дослідницьку задачу. Окрім того, розкриття змісту феноменології дозволяє автору визначити сутнісні ознаки, які відокремлюють цей процес серед інших, та проаналізувати природу і зміст феномену насильства.

Термін «феноменологія» походить від грецьких слів phainómenon, яке означає «те, що 3'являється» i lógos- вчення [4].

Як наука феноменологія спирається на явища, факти, події (феномени) і представляє собою самостійну наукову галузь у системі те- оретичного суспільствознавства - науки про суспільство і його закони» [5, с.8]. Феноменологія грунтується на положеннях філософського методу виявлення явищ - феноменів у реальній дійсності, вивчення їх природи та соціальних відносин, які виникають у зв'язку 3 їх сприйняттям [6, с.103].

Німецький філософ I. Кант (1724-1804) визначав феноменологію як вчення про емпіричні явища, феномени [7, с.163]. Засновник феноменології Е. Гуссерль (1859-1938), феноменологію в основному розглядав та вивчав як структуру свідомості й явища, які в ній відбуваються [7, с.220].

Феноменологія злочинності, будучи одним iз аспектів загальної феноменології суспільства, одночасно є вченням про форми прояву злочинності, а відтак є окремою дисципліною кримінології, яка займається вивченням конкретних форм злочинності, конкретних злочинів і кримінальних сфер [6, с.103].

P. Веприцький у монографічному дослідженні «Феноменологія злочинності в регіоні» (2014) наголошує, що для ефективної боротьби з будь-чим, треба, насамперед, знати якомога більше про протидіючу сторону. Феноменологія злочинності не тільки досліджує злочинність у конкретних формах, а й виробляє заходи протидії саме конкретній злочинності» [8, с.11].

Беручи до уваги, що злочинність це соціальне явище, яке взаємозв'язане 3 усіма сферами громадського життя, у тому числі 3 інститутом сім'і, і сім'я є найбільш значимим чинником формування людської поведінки, то негативні чинники соціального середовища впливають на особу тим більше, якщо існують несприятливі чинники більш глобального характеру, на що опосередковано вказував у межах феноменологічного підходу до праворозуміння Е. Гуссерль, активно розробляючи концепцію «життєвого світу», який на переконання вченого, є сукупністю всіх можливих чи справжніх горизонтів досвіду людського життя та не вимагає підтвердження чи доведення [9, с. 42].

Саме таке розуміння життєвого світу було використане одним із послідовників Е. Гуссерля - М. Хайдеггером. Щодо правової проблематики (що відповідно кореспондує й з тематикою даного дослідження), М. Хайдеггер 
на перший план виносить проблему діалогу в праві, внаслідок того, що самотність індивіда серед інших людей стала наслідком його тотальної нездатності до діалогу [10, с. 31].У. Ауйжпен стверджував, людське існування це завжди співіснування з іншими, а таке співіснування природно не позбавлене конфліктів [11, с. 111-113]. Ця теза цілком і повністю є застосовною і до відносин у середині сім'ї як ланці сучасного суспільства.

Сторони конфлікту, як і насильства, завжди представлені суб'єктами. На думкуГ. Штракса, «де суб’єкта немає - не може бути конфлікту» [12, с.57]. Як справедливо зазначають $\mathcal{~}$. Кіркхоффа, С. Чебакова, «якщо не будеш розмовляти з ворогом, твоя війна ніколи не закінчиться, і ти не дізнаєшся, що таке мир» [13, с. 23]. Німецький філософ і соціолог Г. Зіммель (1858-1918) вважав, що конфлікти не повинні бути швидкими, так як це не завжди призводить до змін в системі, але підвищує ступінь інтеграції. А насильство в конфліктах збільшується, коли супроводжується сильною емоційною участю і коли сторони не мають чітких цілей [14, с. 61]. Американський соціолог Р. Коллінз стверджує, що конфлікт є центральним процесом суспільного життя. Конфлікт, на думку вченого, виникає там, де $є$ насильницький примус. А держава виступає головним засобом контролю над виявами насилля [15]. Для виникнення та розвитку конфлікту очевидного значення набуває усвідомлення його причин та глибини відповідними групами людей, які відчувають ущемлення будь-якого важливого для них інтересу, але щоб конфлікт став реальністю, необхідна реальна соціальна дія. Але і дотепер, не існує такої системи, яка $б$ задовольнила всі інтереси, цілі, прагнення кожного індивіда, групи людей чи цілого суспільства і при цьому цілі, прагнення, погляди, інтереси людей не можуть ідеально співпадати та не суперечити одні одним, які б умови не були надані людиHi.

Англійський філософ Р. Дарендорф (1929 2009) вважав, що чим кращі «умови», тим вищі ймовірність конфлікту і тим більша небезпека того, що протистояння переросте в гострий i насильницький характер [16 , с. 143]. Наприклад, у сімейних стосунках, такими умовами є: емоційний фон, ціннісні установки і спосіб життя членів сім’і; умови життя сім’і; вплив «третіх осіб», зацікавлених у результаті конфлікту; стереотипи поведінки тощо.

Названі нами умови в суб'єктивно інтерпретаційному контексті сприяють виробленню тієї чи іншої стратегії поведінки опонентів (у тому числі й членів сім’і) у конфлікті. С. Соколов відмічав, що саме конфлікти є джерелами і причинами насильницьких дій в будьяких соціальних відносинах [17, с. 115-117]. 3 метою якнайглибше зрозуміти феноменологію насильства вказаний вчений визначав його детермінанти: психічне джерело, - сфера неусвідомленого в людині, «тінь» у поняттях К. Юнга, а також архетипи колективного неусвідомленого, що містять ворожі інстинкти, котрі виявляються за певних умов (обмеження потреб, неявні загрози, суперництво тощо); такі чинники насильства мають невмотивований характер; асоціальний досвід, надбаний в сім'і, у колективі або через 3МI, коли насильство стає результатом засвоєння субмоделей соціальної поведінки, передусім у специфічному оточенні (армія, тюрма, секта, злочинна група); соціальна нерівність (матеріальна, статусна, економічна, політична, расова, етнічна, духовна) також породжує конфліктні ситуації, що створюють джерела соціальної напруги і насильницьких дій (класова боротьба, жорсткі економічні війни, расовий чи етнічний геноцид тощо).

Р. Дарендорф (1929 - 2009) вказував на те, що інтенсивність конфлікту і форми його вираження - різні характеристики, хоча може здатися, що застосування насильства обов'язково характеризує інтенсивний конфлікт. Aле у визначенні форми реалізації протистояння необхідно брати до уваги те, що вважається насильством. Як правило, вважають, що насильство - це перш за все замах на життя, але в деяких випадках має місце так зване психологічне або ідеологічне насильство [18, с.100].

Зауважимо, що процес формування людської цивілізації у конфліктному середовищі, завжди був пов'язаний 3 проявом насильницьких дій. Війни, революції, захоплення майна, конфлікти, протистояння були присутніми у будь-якому суспільстві, на різних етапах історичного розвитку. Насильство завжди було неодмінним атрибутом людського життя, більше того жодна із форм насильства 


\section{Кримінальне право, кримінальний процес та криміналістика}

не зникли, а навпаки набули інших, більш витончених форм та проявів. Як справедливо визначає Ю. Антонян: «Насильство і жорстокість існують стільки ж, скільки існує людство, i їх застосування давно стало традицією, звичним способом вирішення життєвих проблем» [19, с. 269].

Надаючи феноменологічний аналіз такого явища як домашнє насильство, необхідно визначити, що сутність насильства пов'язане, по-перше, із великим розмаїттям значної кількості форм насилля, яке має тенденцію до появи нових та трансформації вже існуючих, подруге, відсутністю спільного для наук, в чиє предметне поле досліджень входить цей соціальний феномен, єдиного підходу до визначення та інтерпретацій зазначеного поняття, що демонструє розбіжності класифікування конкретного соціального факту як акту насилля [2, с. 269].

Філософський аналіз поняття «насильства» демонструє багатогранність виміру цього явища. У кожну історичну епоху воно відігравало певну роль і характеризувалося особливостями до підходу та визначення самого терміну.

\section{Висновок}

Проблема насильства до теперішнього часу залишається досить складною і повністю не вирішеною, не зважаючи на те, що це питання не обійшов увагою жоден відомий мислитель минулого. Поняття насильство розглядали та пов’язували тільки як замах на життя, застосування фізичної сили чи примусовий вплив до кого-небудь, опір на силу, тощо. Сьогодні існують інші форми насилля: економічне, яке в кримінології практично не досліджене, різні види сексуального насильства (сексуальні домагання, переслідування, примусові аборти, стерилізація жінок, примус до шлюбу, тощо), психологічне та інші, що потребують проведення окремого наукового аналізу і дослідження.

\section{Лiтература}

1. Насильство в сім’ї ( кримінологічний аналіз і запобігання): монографія / А.Б. Блага. - Х. : ФО-П Макаренко, 2014. - 360с.

2. В.М. Слюсар Насилля як субстанційна характеристика соціальних трансформацій дисерт. докт.філос.наук 09.00.03 - соціальна філософія та філософія історії Київ - 2019. 471c.

3. Блага А.Б. Дослідження соціальної природи насильства - теоретичне підгрунтя для кримінологічного аналізу насильства в сім’ї Порівняльно-аналітичне право № 3-2 $2013247-250$ c.

4. Юридична енциклопедія. -Т. 6. - К.: Українська енциклопедія, 2004. - С. 265.

5. Р. С. Веприцький Методологія дослідження феноменології злочинності Вісник кримінологічної асоціації України. 2017. № 1 (15) 67-74c.

6. М.О. Мокряк До проблеми феноменологічної характеристики засобів масової інформації Кримінальне право та кримінологія; кримінально-виконавче право С. 102-107.

7. Кремень В. Г., Ільїн В. В. Філософія: мислителі, ідеї, концепції: підручник. Київ: Книга, 2005. 528 с

8. Р. С. Веприцький Феноменологія злочинності в регіоні :монографія Харків: Золота миля, 2014. - 324 с.

9. Сайфуліна Ю.В., Феноменологічний підхід щодо розуміння права Право і суспільство Вип. 1. 2012 Дніпро. 40-44 с.

10. Сайфуліна Ю.В. Феноменологічний підхід до розуміння права Науковий вісник Чернівецького університету. 2011. Вип. 597. C. 29-33.

11. Luijpen W. Phenomenology of Natural Law. Pittsburg: D. Riedel, 1967. C. 111-113.

12. Колпакова ᄉ.A. Насилие в семье: виктимологический аспект, дифференциация ответственности и вопросы законодательной техники: дис. ... канд. юрид. наук: 12.00.08 Москва, 2007, 232.

13. Підсумки Міжнародної конференції Інструменти діалогу як засобу подолання кризових явищ: міжнародний досвід та перспективи застосування в Україні» 10-12 грудня 2014 р. За заг. редакцією Д.В. Проценко на замовлення ОБСЕ Одеса.2014 60 С.

14. Зиммель Г. Избранные работы / Георг Зиммель ; [пер. с нем. А. Жаровський]. (Серия «Сдвиг парадигмы» Вип. 4. Київ. НикаЦентр, 2006.440 с.

15. Коллинз P. Теория конфликта URL: http://azps.ru/polpsy/lib/konflict_kollinz.html (дата звернення 07.09.2020) 


\section{АНОТАЦІЯ}

Домашне насильство є однією з поширених борм порушення прав людини. У більшості випадків зазначені протиправні дї проти когось iз иленів родини супроводжуються актами агресіи, приниження та жорстокої поведінки. Подібні дї з боку насильника приводять до негативного фізичного, психічного та соціального стану здоров'я постраждалої особи чи, навіть, декількох осіб - членів иієї родини. Як правило, найбільше страждають від домашнього насильства жінки, діти та люди похилого віку.

Держава - основний суб'єкт протидї насильству, а тому органи державної влади повинні сприяти створенню обстановки неприйняття насильства, вживаючи необхідних заходів та створюючи систему захисту жертв, покарання кривдників $i$ запобігання насильству.

Незважаючи на існуюче нормативно-правове забезпечення в сбері протидї та захисту прав $і$ інтересів осіб, що постраждали від домашнього насильства, а також на широку кількість наукових праць, присвячених різним аспектам в иій сфері, проблема домашнъого насильства не втрачає своєї актуальності та потребує теоретичного уточнення та обгрунтування.

Метою статті є дослідження історичних аспектів виникнення домашнъого насильства. Акиентована увага на беноменологічному описові домашнъого насильства як об'єкта кримінологічного дослідження. Здійснено порівняльний аналіз різних точок зору вчених, що обумовлюють еволюиійний характер фбеномену домашнього насильства через призму різних сбер пізнання.

Ключові слова: феноменологія, насильство, домашне насильство, насильство в сім' $і$, сім'я, илен сім'ї, илюб.

16. Darendorf, R. (1994), «Elementsofthetheoryofsocialconflict», Sotsys (Sotsyolohy' cheskyeyssledovanyia), vol. 5, pp. 142-147.

17. Соколов С. В. Социальная конфликтология. М. : ЮНИТИ, 2001. 327 с.

18. Черепанова, Е. С. Философия конфликта : учеб. пособие М-во образования и науки Рос. Федер, Урал. федер. ун-т. - Екатеринбург : изд-во Урал. ун-та. 2016. 196 с.

19. Антонян Ю.М. Криминология. Избранные лекции. М., 2004. - 448 с.

Malynovska Tatyana, Candidate of Jurisprudence, Associate Professor, Leading Researcher, Research Laboratory for Combating Crime, Kharkov National University of Internal Affairs

\section{PHENOMENOLOGY OF DOMESTIC VIOLENCE IN UKRAINIAN LEGAL DOCTRINE}

Domestic violence is one of the most common forms of human rights violations. Indicated illegal actions against a family member are in most cases accompanied by acts of aggression, humiliation and abuse. Such actions by the abuser lead to a negative physical, mental and social health condition of the victim or even several persons - members of the family. As a rule, women, children and the elderly suffer the most from domestic violence.

The state is the main subject of combating the violence, and therefore the public authorities should assist in creating the environment of non-acceptance of violence, taking the necessary measures and creating the system of protection of victims, punishment of perpetrators and prevention of violence.

Despite the existing regulatory provision in the field of combating and protecting the rights and interests of victims of domestic violence, as well as a wide range of scientific papers on various aspects in this area, the problem of domestic violence remains relevant and needs theoretical clarification and justification.

The purpose of the article is to study the historical aspects of the origin of domestic violence. The emphasis has been placed on the phenomenological description of domestic violence as an object of criminological research. The author has carried out a comparative analysis of different points of view of scholars, which determine the evolutionary nature of the phenomenon of domestic violence through the prism of different areas of knowledge.

Keywords: fenomenolohiya, nasylstvo, domashnye nasylstvo, nasylstvo v sim'yi, sim'ya, chlen sim'yi, shlyub 